\title{
Preliminary investigation of mineral content of pollen collected from different Serbian maize hybrids - is there any potential nutritional value?
}

\author{
Aleksandar Ž Kostić,, ${ }^{a^{*}}$ Lazar M Kaluderović, ${ }^{b}$ Biljana P Dojčinović, ${ }^{c}$ Miroljub \\ B Barać, ${ }^{a}$ Vojka B Babićd and Marina P Mačukanović-Jocićc
}

\begin{abstract}
BACKGROUND: Bee pollen has already proved to be a good supplement rich in iron and zinc. Studies on the application of flower pollen in the food industry and medicine have begun. Bearing in mind the prevalence of maize as a crop culture, its pollen will be easily available. The mineral composition of pollen of seven Serbian maize hybrids was analyzed in order to establish its nutritional value and the benefits of its implementation in the human diet using the inductively coupled plasma method.

RESULTS: The presence of twenty four different macro- (nine) and micronutrients (fifteen) was detected. The most common minerals were phosphorus and potassium, while arsenic, cobalt, lead, nickel and molybdenum were found in some samples.

CONCLUSION: Comparing the results obtained with recommended or tolerable dietary intake references for adults, it was found that maize pollen can be used as a very good source of zinc, iron, chromium and manganese for humans. With regard to selenium content, pollen samples proved to be moderately good source of this important micronutrient. Contents of some elements (Fe, $\mathrm{Zn}, \mathrm{Mn}, \mathrm{Cr}, \mathrm{Se}, \mathrm{Al}$ and V) showed significant differences depending on hybrid type. In some samples increased concentrations of aluminum and vanadium were recorded, which may pose a potential problem due to their toxicity.
\end{abstract}

(c) 2016 Society of Chemical Industry

Keywords: maize; pollen; minerals; nutritional value

\section{INTRODUCTION}

Zea mays L., commonly known as maize or corn, is usually outcrossed, with a low rate of self-pollination. ${ }^{1}$ The viability period of individual pollen grains is short, and on a whole-field basis cross-pollination could occur over a 7-day period. ${ }^{2}$ Despite being a wind-pollinated plant, ${ }^{3}$ it is not rare for bees, and some other insect pollinators, to visit maize and use it as a source of pollen, especially during the low blooming period of zoophilous plants. ${ }^{4-7}$ In accordance with this, Kostić et al. ${ }^{8}$ reported the presence of maize pollen in several samples of bee-collected pollen from Serbia. In addition, Feil and Schmidt $^{9}$ found that maize tassel was visited by honeybees; however, since they have not been observed on female inflorescences, pollination by honeybees is excluded.

The chemical composition of pollen and its use for nutritional, medicinal and other purposes have been analyzed previously, especially in the last decade, but to a limited extent. The first, preliminary, report of the general chemical composition of maize pollen was given by Anderson and Kulp. ${ }^{10}$ By examining pollen (ten minerals) from five different maize genotypes, Pfahler and Linskens ${ }^{11}$ found significant differences in content of $\mathrm{Al}, \mathrm{Ca}, \mathrm{Fe}$ and K. Recently some studies were conducted on the application of floral ${ }^{12}$ or bee-collected pollen ${ }^{13-17}$ in the nutrition of farm animals raised for meat production. Krystijan et al. ${ }^{18}$ used bee-collected pollen as a food supplement in the biscuit-making process. Also, Atwe et al. ${ }^{19}$ suggested that it was possible to use pollen grains as a modular system for painless oral vaccination.

It is known that maize pollen is of poor quality as a source of amino acids and proteins for humans, ${ }^{20}$ but there is no information on the nutritional value deriving from the contained minerals. This type of research is especially important if it is known that bee-collected pollen is the best source of minerals compared to other bee products, ${ }^{21}$ with particular emphasis on high iron

\footnotetext{
Correspondence to: AZ Kostić, Department of Chemistry and Biochemistry, Faculty of Agriculture, University of Belgrade, Nemanjina 6, 11080 Zemun, Belgrade, Serbia.E-mail: akostic@agrif.bg.ac.rs

a Department of Chemistry and Biochemistry, Faculty of Agriculture, University of Belgrade, 11080 Belgrade, Serbia

b Department of Pedology and Geology, Faculty of Agriculture, University of Belgrade, 11080 Belgrade, Serbia

c Institute of Chemistry, Technology and Metallurgy, University of Belgrade, 11000 Belgrade, Serbia

d Maize Research Institute Zemun Polje, 11185 Belgrade, Serbia

e Department of Agrobotany, Faculty of Agriculture, University of Belgrade, 11080 Belgrade, Serbia
} 
and zinc content. ${ }^{22}$ The present research has provided a detailed review of the mineral composition of pollen collected from seven maize hybrids from Serbia, with reference to twenty four significant macro- and microelements, in order to establish its nutritional value and the benefits of its implementation in the human diet.

\section{MATERIALS AND METHODS}

\section{Study area and samples}

Zea mays $\mathrm{L}$. is anemophilous plant, belonging to the grass family (Poaceae). It is a monoecious plant, producing separate male and female inflorescences. The pollen samples were collected from seven maize hybrids grown in Serbia, in June 2015, applying the method of Pfahler. ${ }^{23}$ All samples originate from the study field (arable land) of the Maize Research Institute - Zemunsko Polje/Beograd (Belgrade), which represents the leading institution in the development, production and introduction of new high-yielding, quality maize hybrids and soybean cultivars, adapted to diverse agro-ecological conditions and growing practices, and suitable for various purposes and uses in Serbia and the whole Balkan region. After collection, all samples were packed into the vacuum bags filled with silica gel to prevent absorption of moisture into the samples. Samples were stored and kept in a refrigerator at a temperature of $4^{\circ} \mathrm{C}$ until analysis.

Zemunsko Polje settlement $\left(44^{\circ} 52^{\prime} \mathrm{N}, 20^{\circ} 19^{\prime} \mathrm{E}\right.$, Fig. 1) is part of Zemun municipality and is located in the easternmost region of Belgrade, near the highway to Novi Sad.

Pollen was collected from seven maize hybrids that were produced and developed in this Institute during the past several decades: ZP Standard (yellow grain) (sample 1, S01); ZP $608 \mathrm{~K}$ (sample 2, S02); ZP 611 K (sample 3, S03); L 620/121 - 'sweet corn' (sample 4, S04); Lady Fingers (sample 5, S05); ZP Rumenka (sample 6, S06); and ZP 555 (sample 7, S07).

\section{Analytical methods}

Determination of mineral elements was carried out using inductively coupled plasma-optical emission spectrometry (ICP-OES) with previous microwave digestion of samples. ${ }^{22}$

\section{Statistical analysis}

For statistical data analysis the Statistica 8 program (StatSoft Co., Tulsa, OK, USA) was used. Results are expressed as the mean value of three measurements \pm standard deviation. The obtained results underwent Duncan's multiple range test to determine whether there were significant differences between samples and mineral content $(P<0.01)$.

\section{RESULTS AND DISCUSSION}

Comparing the content of selected macro- and microelements in the investigated hybrids, significant differences for certain minerals have been established. Macroelements $\left(\mathrm{g} \mathrm{kg}^{-1}\right)$ contained in samples of maize pollen are given in Table 1.

ICP-OES analysis revealed that the two most common minerals in all pollen samples are phosphorus (1, 5, 6 and 7$)$ and potassium (2, 3 and 4) (Table 1). Pfahler and Linskens, ${ }^{11}$ also, found these two elements to prevail in the pollen of five different genotypes of maize. These results were expected if one bears in mind the importance of these two elements for the plant. ${ }^{24}$

High content of phosphorus, especially, is characteristic of seeds. ${ }^{25}$ According to the Food and Nutrition Board Standing

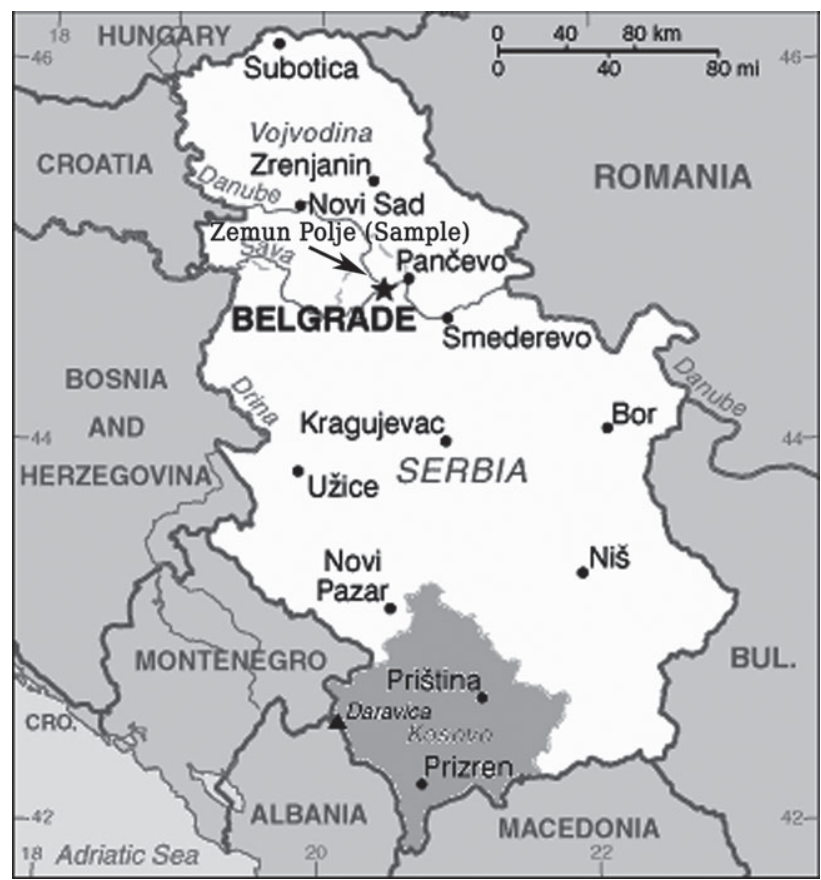

Figure 1. Geographical map of the study area indicating experimental field

Committee (NBSC) of the US National Academies, the recommended dietary intake (RDI) with reference to phosphorus ${ }^{26}$ and potassium ${ }^{27}$ for adults is 0.7 and $4.7 \mathrm{~g} \mathrm{~d}^{-1}$, respectively. The results have shown that consumption of about $100 \mathrm{~g}$ (101.9-126.6 g) pollen as a food supplement could meet daily requirements for phosphorus for an adult person, depending on type of hybrids. In the case of potassium, $100 \mathrm{~g}$ pollen could meet $12-18 \%$ of daily intake.

The analyzed pollen samples have a relatively high sulfur content, ranging from 2.39 to $3.04 \mathrm{~g} \mathrm{~kg}^{-1}$. Its high content is expected since this element plays an important role in biosynthesis of amino acids, proteins and some vitamins. Deficiency could lead to abnormal growth of some parts of plants or to the discoloration of tissues. ${ }^{28}$ In the human body it is the third most abundant element and it is essential for animals and humans, since only plants and bacteria can synthesize organic $S$ compounds. ${ }^{29}$ Estimated dietary intake of sulfur for humans (in the form of organic $S$ from food) is $2.8 \mathrm{~g} \mathrm{~d}^{-1} .^{27}$ In that case, consumption of $100 \mathrm{~g}$ maize pollen would fulfill $8.5-10.9 \%$ of daily intake.

With respect to the content of magnesium $\left(0.73-1.03 \mathrm{~g} \mathrm{~kg}^{-1}\right)$ and calcium $\left(0.45-0.65 \mathrm{~g} \mathrm{~kg}^{-1}\right)$, a lower content of these two elements, and in particular of calcium, relative to phosphorus, is a characteristic for the plant parts that are associated with the seed. ${ }^{25}$ Bearing in mind the importance and role of these two elements in the human body, ${ }^{30} \mathrm{RDI}$ values for adults are relatively high: $0.42 \mathrm{~g} \mathrm{~d}^{-1}$ for magnesium and $1 \mathrm{~g} \mathrm{~d}^{-1}$ for calcium. ${ }^{26}$ Comparing the content of these two elements in maize pollen with tolerable upper intake (TUI) level it can be realized that the consumption of $100 \mathrm{~g}$ pollen per day satisfies about $20 \%$ (17.4-24.6\%) of daily intake for magnesium and about 5\% (4.5-6.5\%) for calcium.

Zinc as a nutrient is relatively harmless in comparison with some other similar transition metals. ${ }^{31}$ The main source of zinc in food for humans in developing countries are cereals and pulses, while meat, dairy products and cereals are the most important source of zinc in the diet of inhabitants of the USA and other developed countries. ${ }^{32}$ In crop plants, zinc plays an important role in cellular 


\begin{tabular}{l}
$\begin{array}{l}\text { Table 1. Content of macroelements }\left(\mathrm{g} \mathrm{kg}^{-1} \pm \mathrm{SD} \text { ) in pollen samples collected from seven maize hybrids grown in Zemun polje }\right. \\
\text { settlement (Belgrade, Serbia) }\end{array}$ \\
$\begin{array}{l}\text { Sample } \\
\text { label }\end{array}$ \\
\hline K
\end{tabular}

Means with same letter in the same column are not significantly different $(P<0.05)$.

Table 2. Content of microelements $\left(\mathrm{mg} \mathrm{kg}^{-1} \pm \mathrm{SD}\right)$ in maize pollen samples

\begin{tabular}{|c|c|c|c|c|c|c|c|c|}
\hline $\begin{array}{l}\text { Sampl } \\
\text { label }\end{array}$ & $\mathrm{Al}$ & B & $\mathrm{Cu}$ & $\mathrm{Sr}$ & $\mathrm{Cr}$ & $\mathrm{Cd}$ & $\mathrm{Li}$ & $\mathrm{Sb}$ \\
\hline S01 & $6.85 \pm 0.07$ & $6.51 \pm 0.05$ & $1.89 \pm 0.01$ & $0.50 \pm 0.01$ & $0.113 \pm 0.001$ & $0.026 \pm 0.0006 a$ & $0.0100 \pm 0.0004$ & $0.080 \pm 0.004 a$ \\
\hline S02 & $6.07 \pm 0.02$ & $5.04 \pm 0.04 a$ & $1.80 \pm 0.01$ & $0.95 \pm 0.02 \mathrm{a}$ & $0.094 \pm 0.001$ & $0.009 \pm 0.0002$ & $0.0190 \pm 0.0004 a$ & $0.080 \pm 0.003 a$ \\
\hline S03 & $8.07 \pm 0.19$ & $5.08 \pm 0.11 a$ & $2.33 \pm 0.10 a$ & $0.97 \pm 0.01 \mathrm{a}$ & $0.109 \pm 0.001$ & $0.013 \pm 0.006$ & $0.0180 \pm 0.0008 a$ & $0.098 \pm 0.002$ \\
\hline SO4 & $74.28 \pm 0.99$ & $5.80 \pm 0.13 b$ & $2.24 \pm 0.09 a$ & $0.74 \pm 0.01$ & $0.233 \pm 0.008 a$ & $0.028 \pm 0.0012 a$ & $0.0650 \pm 0.0010$ & $0.047 \pm 0.002$ \\
\hline S05 & $89.65 \pm 0.83$ & $5.55 \pm 0.10 b$ & $2.73 \pm 0.06$ & $0.70 \pm 0.01$ & $0.239 \pm 0.004 a$ & $0.018 \pm 0.0007$ & $0.0790 \pm 0.0015$ & $0.014 \pm 0.001$ \\
\hline S06 & $48.20 \pm 0.68$ & $4.82 \pm 0.22 a$ & $2.31 \pm 0.02 a$ & $0.42 \pm 0.02 b$ & $0.166 \pm 0.003$ & $0.006 \pm 0.0001$ & $0.0420 \pm 0.0015$ & $0.022 \pm 0.001 a$ \\
\hline \multirow[t]{2}{*}{ S07 } & $23.88 \pm 0.99$ & $5.85 \pm 0.28 b$ & $1.74 \pm 0.03$ & $0.40 \pm 0.01 b$ & $0.133 \pm 0.002$ & n.d. & $0.0230 \pm 0.0007$ & $0.024 \pm 0.001 a$ \\
\hline & $\mathrm{Se}$ & Mo & v & $\mathrm{Ni}$ & $\mathrm{Pb}$ & Co & As & \\
\hline S01 & $0.069 \pm 0.002$ & $0.0220 \pm 0.0010$ & $0.0100 \pm 0.0005 a$ & $0.0050 \pm 0.0002$ & $0.0040 \pm 0.0002$ & n.d. & n.d. & \\
\hline S02 & $0.158 \pm 0.008 a$ & $0.026 \pm 0.0004$ & $0.0110 \pm 0.0002 a$ & $0.0070 \pm 0.0002$ & n.d. & n.d. & $0.686 \pm 0.003$ & \\
\hline S03 & $0.176 \pm 0.005 b$ & n.d. & $0.0170 \pm 0.0008$ & n.d. & $0.0490 \pm 0.0013$ & n.d. & $0.032 \pm 0.001$ & \\
\hline SO4 & $0.155 \pm 0.007 a$ & n.d. & $0.1390 \pm 0.0068$ & n.d. & $0.0070 \pm 0.0001$ & $0.070 \pm 0.003$ & n.d. & \\
\hline S05 & $0.073 \pm 0.002$ & n.d. & $0.1650 \pm 0.0828$ & $0.0080 \pm 0.0008$ & n.d. & $0.017 \pm 0.001$ & n.d. & \\
\hline S06 & $0.172 \pm 0.004 b$ & $0.009 \pm 0.0001$ & $0.0940 \pm 0.0025$ & n.d. & n.d. & $0.0080 \pm 0.0001$ & n.d. & \\
\hline S07 & $0.176 \pm 0.008 b$ & $0.007 \pm 0.0001$ & $0.0410 \pm 0.0006$ & $0.0110 \pm 0.0010$ & n.d. & n.d. & n.d. & \\
\hline
\end{tabular}

metabolic processes since it can participate in redox reactions because of the presence of one unpaired electron. ${ }^{33}$

Similar properties are possessed by iron, which is the reason why these two elements are competitive in the nutrition process $^{34}$ and why the presence of ferrous iron in food (especially in food supplements) can decrease absorption of zinc..$^{32}$ In humans, the main amount of iron is presented in the form of the heme group of hemoglobin and myoglobin, while the presence of zinc is associated with the immune system, cell division and growth, and prostate functionality in men. ${ }^{33}$ Comparing amounts of these elements in maize pollen ( $\mathrm{Zn}$ : $0.041-0.062 \mathrm{~g} \mathrm{~kg}^{-1}$; Fe: $0.019-0.076 \mathrm{~g} \mathrm{~kg}^{-1}$ ) with the RDI level for an adult person ( $\mathrm{Zn}$ : $0.011 \mathrm{~g} \mathrm{~d}^{-1}$; Fe: $0.008 \mathrm{~g} \mathrm{~d}^{-1}$ ), it can be observed that there is a significant difference for both elements depending on hybrid type. For instance, consumption of $100 \mathrm{~g}$ 'Lady Fingers' hybrid maize pollen can meet almost $95 \%$ of the daily need for iron. On the other hand, ZP standard, ZP608K and ZP611K hybrids contain much smaller quantities of iron and could cater for about $25-30 \%$ of daily intake of this mineral. In the case of zinc, differences between hybrids are smaller $(36.8-56.8 \%)$ but still a high ratio compared to the recommended dietary allowance for zinc. Bearing in mind that bee-collected pollen has been proven to be the best source of zinc and iron of all bee products, ${ }^{21}$ and that consumption of Serbian bee-collected pollen could satisfy $30 \%$ of the daily adult human requirement for iron and $15 \%$ for zinc, ${ }^{22}$ it can clearly be seen that maize pollen is also an excellent source of these two nutrients for humans.

The presence of sodium in the investigated samples $\left(0.0074-0.041 \mathrm{~g} \mathrm{~kg}^{-1}\right)$ is of negligible nutritional importance considering the high daily need for this mineral in the diet $1.5 \mathrm{~g}$ $\mathrm{d}^{-1}$ ).

Young plant organs are rich in manganese, an element that plays an important role in redox processes in the plant (photosynthesis) and as an important co-factor in 35 different enzymes. ${ }^{35}$ Accordingly, a relatively high amount of manganese in maize pollen has been found $\left(0.014-0.021 \mathrm{~g} \mathrm{~kg}^{-1}\right)$. In humans, manganese also plays an important role as a co-factor for various enzymes. ${ }^{26}$ Adequate dietary intake $\mathrm{e}^{36}$ is $0.0023 \mathrm{~g} \mathrm{~d}^{-1}$. Comparing this value to the content of manganese in the pollen, a high level of coverage of the human daily requirement (61.7-91.3\%) can be observed, if $100 \mathrm{~g}$ maize pollen is consumed.

Results for the content of microelements $\left(<0.01 \mathrm{~g} \mathrm{~kg}^{-1}\right)$ presented in maize pollen samples are given in Table 2. 
Table 3. The average content of macroelements $\left(\mathrm{g} \mathrm{kg}^{-1}\right)$ and microelements $\left(\mathrm{g} \mathrm{kg}^{-1}\right)$ in some food types in comparison with maize pollen samples $^{51,52}$

\begin{tabular}{|c|c|c|c|c|c|c|c|c|}
\hline Food type & Milk & Cheeses & Butter & Yoghurt & Corn flakes* & Maize kernel* & Pollen & Higer $(\uparrow)$ Lower $(\downarrow)$ Equal $(=)$ \\
\hline \multicolumn{9}{|c|}{ Macroelements } \\
\hline K & $1.44-1.78$ & $0.77-1.6$ & 0.15 & 2.8 & 1.2 & 2.94 & $5.11-7.76$ & $\uparrow$ \\
\hline$P$ & $0.63-1.02$ & $1-8.1$ & 0.24 & 1.7 & 0.059 & 2.13 & $5.53-6.87$ & $\uparrow$ \\
\hline $\mathrm{Ca}$ & $1.07-1.33$ & $0.73-12$ & 0.15 & 2 & 0.13 & 0.08 & $0.40-0.65$ & $\downarrow$ or $=$ \\
\hline $\mathrm{Na}$ & $0.4-0.58$ & $3-14.4$ & 0.11 & 0.8 & 9.15 & 0.06 & $0.007-0.041$ & $\downarrow$ \\
\hline $\mathrm{Mg}$ & $0.09-0.16$ & $0.09-0.45$ & 0.02 & 0.19 & I & / & $0.73-1.03$ & $\uparrow$ \\
\hline$S$ & 0.32 & / & / & / & / & / & $2.39-3.04$ & $\uparrow$ \\
\hline \multicolumn{9}{|c|}{ Microelements } \\
\hline $\mathrm{Zn}$ & $0.74-1.45$ & $5-53$ & 1 & 7 & / & / & $41-62$ & $\uparrow$ \\
\hline $\mathrm{Fe}$ & $0.3-0.7$ & $1-8$ & 2 & 1 & 0.02 & 0.015 & $19-76$ & $\uparrow$ \\
\hline $\mathrm{Mn}$ & $0.013-0.04$ & $<1$ & I & l & & & $11-21$ & $\uparrow$ \\
\hline $\mathrm{Cu}$ & $0.02-0.3$ & $<0.0033$ & 0.0003 & l & & & $1.74-2.73$ & $\uparrow$ \\
\hline $\mathrm{Se}$ & $0.013-0.017$ & $0.01-0.12$ & I & 0.02 & & & $0.069-0.176$ & $\uparrow$ \\
\hline Co & $0.5-1.3$ & & & & & & $<0.07$ & $\downarrow$ \\
\hline $\mathrm{Ni}$ & $0.004-0.06$ & & & & & & $<0.011$ & $\uparrow$ or $=$ \\
\hline Mo & $0.024-0.06$ & & & & & & $<0.026$ & $\downarrow$ \\
\hline $\mathrm{B}$ & $0.19-0.95$ & & & & & & $4.82-6.51$ & $\uparrow$ \\
\hline $\mathrm{Cr}$ & $0.01-0.04$ & & & & & & $0.094-0.239$ & $\uparrow$ \\
\hline $\mathrm{Al}$ & 0.46 & & & & & & $6.07-89.65$ & $\uparrow$ \\
\hline
\end{tabular}

Aluminum is one of the most toxic metals for plants. ${ }^{37-39} \mathrm{Gen}-$ erally, aluminum level in plants does not exceed $0.2 \mathrm{~g} \mathrm{~kg}^{-1}$ dry mass $^{37}$ but there are plant species known as Al-accumulator species, such as tea plant ${ }^{40}$ or oats, ${ }^{38}$ which can normally develop despite the high amount of this element in the substrate. Unlike tea plant and oats, maize represents Al-sensitive plant species. ${ }^{38}$ Considering the significant presence of aluminum in many soils in the form of aluminosilicates and hydroxides, its biggest influence is on the root of the plant and its proper development. ${ }^{37,38}$

The main condition for the occurrence of soluble aluminum forms that plants can absorb is acidic soil. ${ }^{38,39}$ According to the results obtained, there are significant differences in aluminum content between different maize hybrids. Different types of aluminosilicate in combination with acidic soil character were responsible for the occurrence of aluminum in maize samples. A tenfold greater amount of aluminum present in three $(4,5$ and 6$)$ of the seven samples can be related to a locally larger amount of aluminosilicate and more preferred $\mathrm{pH}$ value in the part of the field where hybrids were grown. Considering that the transfer of aluminum is slow from the root to the above-ground plant parts, ${ }^{41}$ there is a high chance that the contamination occurred under the anthropogenic influence. As a part of Belgrade, Zemunsko Polje is an urban area in the vicinity of roads and railways and relatively close to the airport. As confirmation of these observations, Kostic et al. ${ }^{22}$ reported the presence of aluminum in two bee pollen samples collected in the Belgrade area. Toxicity of aluminum for humans has been demonstrated through neurotoxicity and autoimmunity for adults and as vaccine adjuvants for children. ${ }^{42}$ Since provisional tolerable weekly intake (PTWI) for adults is $0.07 \mathrm{~g} \mathrm{~kg}^{-1}, 42$ it can be observed that in the case of consumption of two pollen samples ( 4 and 5 ) this limit will be overcome.

The presence of boron in drinking water and, generally, in food is undesirable because of its potentially harmful impact on human health. ${ }^{43}$ According to the $\mathrm{NBSC}^{36}$ the tolerant level of boron in food is $0.02 \mathrm{~g} \mathrm{~d}^{-1}$. In this sense, ingesting $100 \mathrm{~g}$ pollen as food supplement $(0.0004-0.0006 \mathrm{~g}$ boron) would not have a detrimental effect on health.

Copper, as an essential microelement for the functioning of many enzymes, especially in hematological and neurological systems $\mathrm{s}^{25,44}$ in the human body, has a recommended daily intake level of $0.0009 \mathrm{~g} \mathrm{~d}^{-1} .{ }^{36}$ According to the results obtained for maize pollen, $19-30 \%$ of the daily requirement may be satisfied through its consumption as a food supplement. Although most of the orally ingested copper would not be absorbed, excess dietary intake might cause accumulation in the liver and intoxication of the organism. ${ }^{25}$

In the case of chromium, with an RDI of $3.5 \times 10^{-5} \mathrm{~g} \mathrm{~d}^{-1}, 36$ maize pollen has shown great ability to fulfill that requisite $(25.7-68.6 \%$ of RDI). The presence of chromium in all samples was expected, having in mind its presence in chromite mineral as well as its possible presence in garnets, epidote and other minerals, which were also detected in surrounding soil. The importance of chromium for humans is reflected in the influence of chromium(III) ions as essential micronutrients. On the other hand, $\mathrm{Cr}(\mathrm{VI})$ is a carcinogenic form, but it is important to note that it may be easily reduced to $\mathrm{Cr}(\mathrm{III})$, either in soil or in the gastrointestinal tract. Absorbance of chromium into body is low at about $5 \%$ - similar to copper. ${ }^{45}$

Selenium is an important microelement with pronounced antioxidant capacity (synergistic with vitamin E). Organic forms of selenium are more important than inorganic because of higher solubility. ${ }^{25}$ The RDI for this element ${ }^{46}$ is $5.5 \times 10^{-5} \mathrm{~g} \mathrm{~d}^{-1}$, which makes pollen samples a potentially good source in diet (12.5-32\% of RDI).

The amount of vanadium in samples 4 and 5 was about 15 times higher than in the other samples, which may indicate anthropogenic contamination. The main source of vanadium in the environment is combustion of fossil fuels or road-fill materials and cement. ${ }^{47,48}$ Even so, it still cannot be claimed there are indications that exposure to elevated concentrations of vanadium is harmful and potentially carcinogenic. ${ }^{49}$ Because of that, $\mathrm{NBCS}^{37}$ gave a relatively low tolerable daily intake level $\left(0.0018 \mathrm{~g} \mathrm{~d}^{-1}\right)$. Results have 


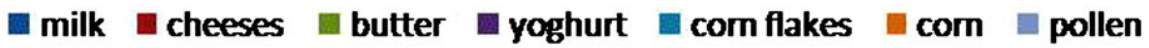

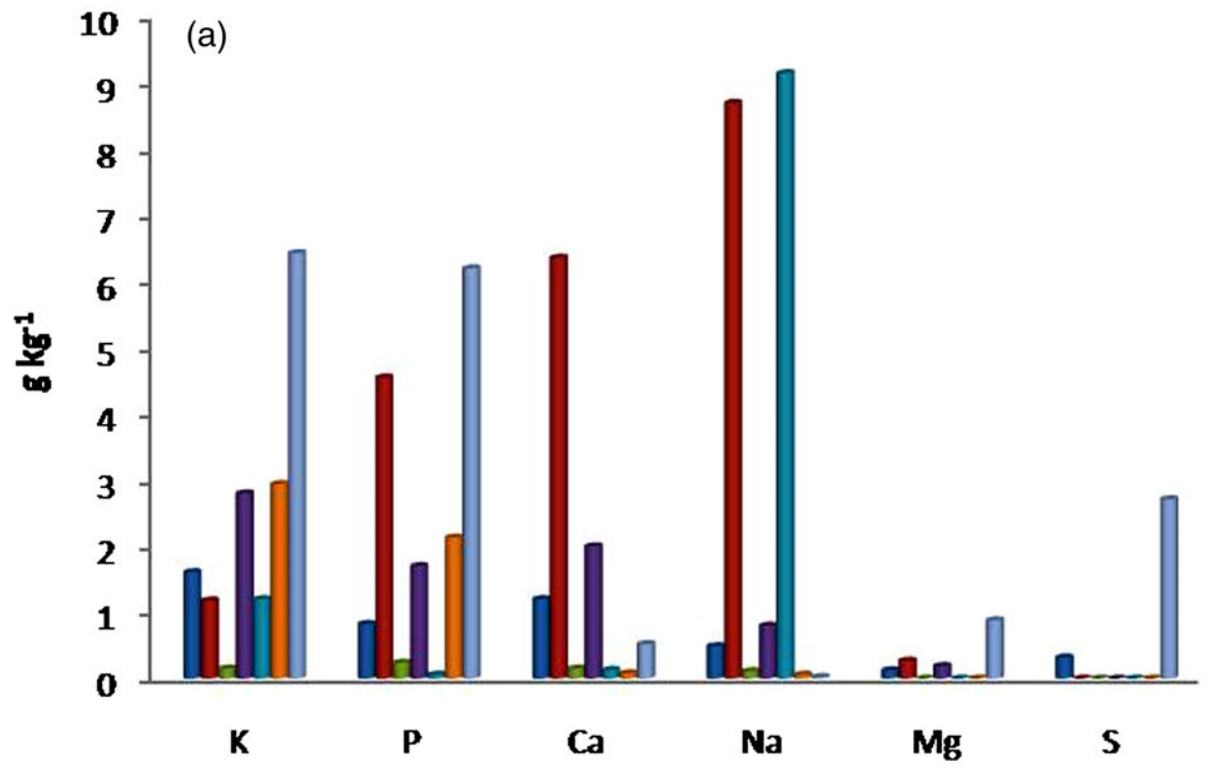

milk $\square$ cheeses $\|$ butter $\square$ yoghurt $\square$ comflakes $\square$ com $\square$ pollen

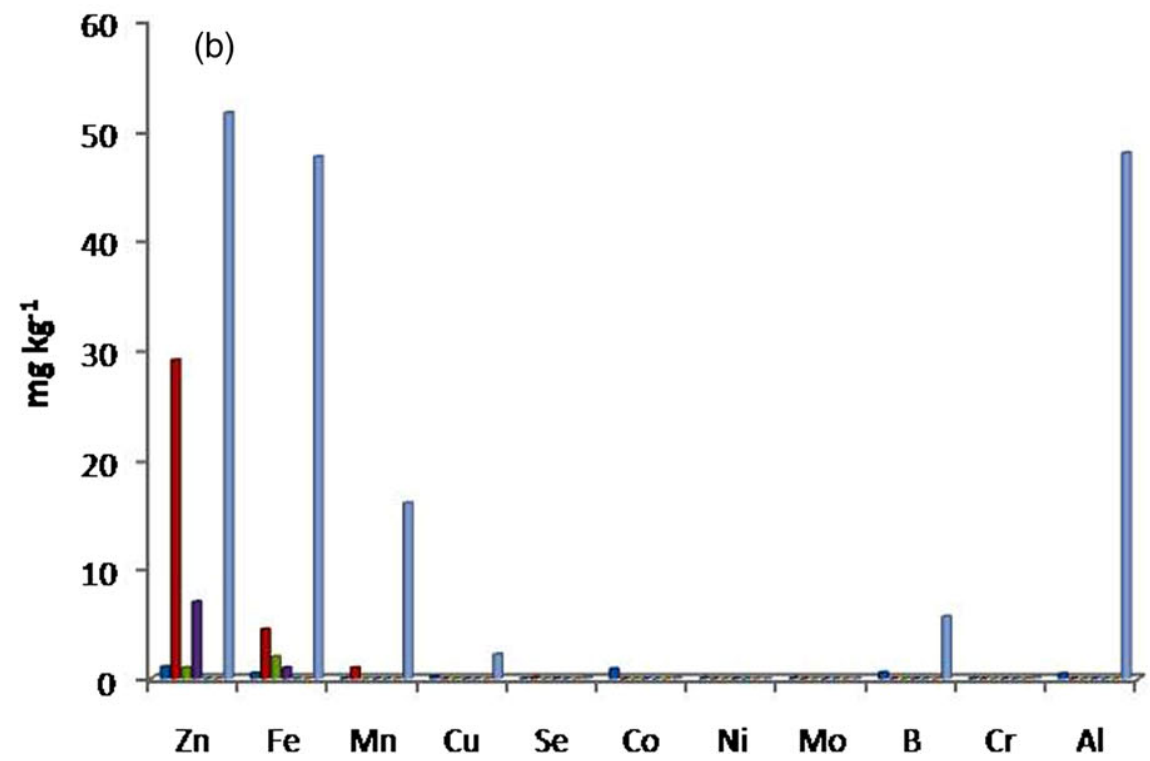

Figure 2. Comparison of mineral content in pollen and different types of food: (a) macroelements; (b) microelements.

shown that consumption of $100 \mathrm{~g}$ pollen may satisfy about $50 \%$ of this value in the case of four samples, or may significantly exceed that amount (about 900\%) in samples with an elevated concentration of vanadium. In the case of some trace, toxic elements, Campos et al. ${ }^{50}$ suggest limit values in bee pollen: $0.0001 \mathrm{~g} \mathrm{~kg}^{-1}$ for cadmium and $0.0005 \mathrm{~g} \mathrm{~kg}^{-1}$ for lead and arsenic. In all samples these three elements were within permitted boundaries, except in the case of arsenic in sample 2, with elevated concentration $\left(0.00069 \mathrm{~g} \mathrm{~kg}^{-1}\right)$.

Previously, Kostić et al. ${ }^{22}$ reported the presence of strontium in bee pollen for the first time in the literature, with a mean value of $0.00138 \mathrm{~g} \mathrm{~kg}^{-1}$. In this case the limits were a little lower $\left(0.0004-0.00097 \mathrm{~g} \mathrm{~kg}^{-1}\right)$ but, in any case the presence of this element in food supplements is undesirable because of its toxicity for humans. All other microelements were detected in traces or not detected at all in the investigated maize pollen samples.

The average mineral content in food can vary significantly depending on type. In Table 3 the mineral content of different dairy products, ${ }^{51}$ maize kernel and corn flakes ${ }^{52}$ is shown, together with values for macro- and microelements in investigated pollen samples. If obtained results are compared with these types of food, the higher content of $\mathrm{K}, \mathrm{P}, \mathrm{Mg}$ and $\mathrm{S}$ in pollen samples can be observed, as well as for Zn, Fe, Mn, Cu, B and Al (Fig. 2a, b). 


\section{CONCLUSIONS}

According to the results obtained there are significant differences between seven maize pollen samples of Serbian hybrids related to some macro- and microelements: iron, zinc, manganese, aluminum, chromium, selenium and vanadium. Also, a beneficial nutritional potential of maize pollen was observed if applied as a food supplement in human diet. Floral pollen has shown better nutritional characteristics in regard to iron and zinc content compared to bee pollen. Chromium and manganese presented in pollen can fulfill a meaningful $(\mathrm{Cr})$ or major portion $(\mathrm{Mn})$ of the needs for these nutrients in the diet. The presence of aluminum, vanadium and strontium in pollen can represent potential problem due to their toxicity to humans.

\section{ACKNOWLEDGEMENTS}

The research was financially supported by the Ministry of Education, Science and Technological Development of the Republic of Serbia (Grant Nos. TR 31069 and 46009), as well as by EU Commission Project AREA, No. 316004.

\section{REFERENCES}

1 Sleper DA and Poehlman JM, Breeding corn (maize), in Breeding Field Crops (5th edn). Blackwell, Oxford, pp. 277-296 (2006).

2 Bannert $M$ and Stamp P, Cross-pollination of maize at long distance. Eur J Agron 27:44-51 (2007).

3 EOLSS, Growth and production of maize: traditional low input cultivation, in Soils, Plant Growth and Crop Production, ed. by Verheye WH. Encyclopedia of Life of Life Support Systems (EOLSS), Vol. II. EOLSS, Oxford, ch. 21 (2010).

4 Severson DW and Parry JE, A chronology of pollen collection by honeybees. J Apic Res 20:97-103 (1981).

5 Baum KA, Rubink WI, Coulson RN and Bryant VN, Pollen selection by feral honey bee (Hymenoptera: Apidae) colonies in a coastal prairie landscape. Environ Entomol 54:727-739 (2004).

6 Malerbo-Souza DT, The maize pollen as a food source for honeybees. Acta Sci Agron 33:701-704 (2011).

7 Höcherl N, Siede R, Illies I, Gätschenberger H and Tautz J, Evaluation of the nutritive value of maize for honey bees. J Insect Physiol 58:278-285 (2012).

8 Kostić AŽ, Barać MB, Stanojević SP, Milojković-Opsenica DM, Tešić ŽLj, Šikoparija B et al., Physicochemical composition and techno-functional properties of bee pollen collected in Serbia. LWT - Food Sci Technol 62:301-309 (2015).

9 Feil B and Schmidt JE, Dispersal of Maize, Wheat and Rye Pollen: A Contribution to Determining the Necessary Isolation Distances for the Cultivation of Transgenic Crops. Shaker, Aachen, Germany (2002).

10 Anderson RJ and Kulp WL, Analysis and composition of maize pollen: preliminary report. J Biol Chem 50:433-454 (1922).

11 Pfahler PL and Linskens HF, Ash percentage and mineral content of maize (Zea mays L.) pollen and style. Theor Appl Genet 45:32-36 (1974).

12 Joo M-J, Jung H, Kim S-H and Yoon W-B, The antibacterial effect of flower pollen on Escherichia coli 0157:h7 in ground pork. J Food Saf 35:355-361 (2015).

13 Šulcerová H, Mihok M, Jůzl M and Haščík P, Effect of addition of pollen and propolis to feeding mixtures during the production of broiler chickens ROSS 308 to the colour of thigh and breast muscle and $\mathrm{pH}$ determination. Acta Univ Agric Silvic Mendel Brun 59:359-366 (2011).

14 Haščík P, Elimam IOE, Bobko M, Kačániová M, Pochop J, Garlík J et al., Oxidative stability of chicken meat after pollen extract application in their diet. J Microbiol Biotechnol Food Sci 1:70-82 (2011).

15 Haščík P, Elimam I, Garlík J, Bobko M and Čuboň J, The effect of bee pollen as supplement dietary for meat $\mathrm{pH}$, cooling and freezing loses on broiler chickens meat. RFFCH (Animal Welfare, Ethology and Housing System) 9:477-482 (2013).

16 Turhan S, Yazici F, Saricaoglu FT, Mortas M and Genccelep H, Evaluation of the nutritional and storage quality of meatballs formulated with bee pollen. Korean J Food Sci Anim Resour 34:423-433 (2014).
17 Seven PT, Arslan AS, Seven I and Gökçe Z, The effects of dietary bee pollen on lipid peroxidation and fatty acids composition of Japanese quails (Coturnix coturnix japonica) meat under different stocking densities. J Appl Anim Res 44:487-491 (2016).

18 Krystijan M, Gumul D, Ziobro R and Korus A, The fortification of biscuits with bee pollen and its effect on physicochemical and antioxidant properties in biscuits. LWT - Food Sci Technol 63:640-646 (2015).

19 Atwe SU, Ma Y and Singh Gill H, Pollen grains for oral vaccination. $J$ Control Release 194:45-52 (2014).

20 Somerville DC and Nicol HI, Crude protein and amino acid composition of honey bee-collected pollen pellets from south-east Australia and a note on laboratory disparity. Aust J Exp Agric 46:141 - 149 (2006).

21 Serra Bonvehí J and Escolá Jordá R, Nutrient composition and microbiological quality of honeybee-collected pollen in Spain. J Agric Food Chem 45:725-732 (1997).

22 Kostić AŽ, Pešić MB, Mosić MD, Dojčinović BP, Natić MM and Trifković $J \bigoplus$, Mineral content of bee pollen from Serbia. Arh Hig Rada Toksiko 66:251-258 (2015).

23 Pfahler PL, Fertilization ability of maize pollen grains. I. Pollen sources. Genetics 52:513-520 (1965).

24 Fageria NK and Moreira A, The role of mineral nutrition on root growth of crop plants, in Advances in Agronomy, Vol. 110, ed. by Sparks DL. Elsevier, Amsterdam, pp. 252-318 (2011).

25 Soetan KO, Olaiya CO and Oyewole $\mathrm{OE}$, The importance of mineral elements for humans, domestic animals and plants: a review. Afr $J$ Food Sci 4:200-222 (2010).

26 NBSC, Dietary Reference Intakes for Calcium, Phosphorus, Magnesium, Vitamin D, and Fluoride, Standing Committee on the Scientific Evaluation of Dietary Reference Intakes, Food and Nutrition Board, Institute of Medicine. National Academy Press, Washington DC (1997).

27 NBSC, Dietary Reference Intakes for Water, Potassium, Sodium, Chloride, and Sulfate, Standing Committee on the Scientific Evaluation of Dietary Reference Intakes, Food and Nutrition Board, Institute of Medicine. National Academy Press, Washington DC (2005).

28 Sager M, Levels of sulfur as an essential nutrient element in the soil-crop-food system in Austria. Agriculture 2:1-11 (2012).

29 Parcell $S$, Sulfur in human nutrition and applications in medicine. Alter Med Rev 7:22-44 (2002).

30 WHO, Calcium and Magnesium in Drinking Water: Public Health Significance. WHO Press, Geneva, Switzerland (2009).

31 Plum LM, Rink L and Haase $H$, The essential toxin: impact of zinc on human health. Int J Environ Res Pub Health 7:1342-1365 (2010).

32 Nriagu J, Zinc Deficiency in Human Health. Elsevier, Amsterdam (2007).

33 Zargar SM, Mahajan R, Farhat S, Nazir M, Mir RA, Nazir M et al., Understanding the role of iron and zinc in animals and crop plants from genomics perspective. Curr Trends Biotechnol Pharm 9:181-196 (2015).

34 Solomons NW, Competitive interaction of iron and zinc in the diet: consequences for human nutrition. J Nutr 116:927-935 (1986).

35 Mousawi SR, Shahsavari M and Rezaei M, A general overview on manganese (Mn) for crops production. Aust J Basic Appl Sci 5:1799-1803 (2011).

36 NBSC, Dietary Reference Intakes for Vitamin A, Vitamin K, Arsenic, Boron, Chromium, Copper, lodine, Iron, Manganese, Molybdenum, Nickel, Silicon, Vanadium and Zinc, Standing Committee on the Scientific Evaluation of Dietary Reference Intakes, Food and Nutrition Board, Institute of Medicine. National Academy Press, Washington DC (2001).

37 Mossor-Pietraszewska T, Effect of aluminum on plant growth and metabolism: review. Acta Biochim Pol 48:673-686 (2001).

38 Rout G, Samantaray $S$ and Das P, Aluminum toxicity in plants: a review. Agronomie 21:3-21 (2001).

39 Đalović IG, Maksimović IV, Kastori RP and Jelić MŽ, Mechanisms of adaptation of small grains to soil acidity. Proc Nat Sci, Matica Srpska Novi Sad 118:107-120 (2010).

40 Matsumoto H, Hiraseva E, Morimura S and Takahashi E, Localization of aluminum in tea leaves. Plant Cell Physiol 17:627-631 (1976).

$41 \mathrm{Ma} \mathrm{JF}$, Zheng SJ, Matsumoto $\mathrm{H}$ and Hiradate S, Detoxifying aluminum with buckwheat. Nature 390:569-570 (1997).

42 Shaw CA and Tomljenovic L, Aluminum in the central nervous system (CNS): toxicity in humans and animals, vaccine adjuvants and autoimmunity. Immunol Res 56:304-316 (2013).

43 Kostić AŽ, Pantelić NĐ, Kaluđerović LM, Jonaš JP, Dojčinović BP and Popović-Djordjević JB, Physicochemical properties of waters in southern Banat (Serbia): potential leaching of some trace elements from grounds and human health risk. Expos Health 8:227-237 (2016). 
44 Tan JC, Burns DL and Jones HR, Severe ataxia, myelopathy and peripheral neuropathy due to acquired copper deficiency in a patient with history of gastrectomy. J Parenter Enteral Nutr 30:446-445 (2006).

45 WHO, Chromium, in Air Quality Guidelines for Europe (2nd edn). WHO Regional Office for Europe, Copenhagen, ch. 6.4 (2000).

46 NBSC, Dietary Reference Intakes for Vitamin C, Vitamin E, Selenium and Carotenoids, Standing Committee on the Scientific Evaluation of Dietary Reference Intakes, Food and Nutrition Board, Institute of Medicine. National Academy Press, Washington DC (2000).

47 Pacyna JM and Pacyna EG, An assessment of global and regional emissions of trace metals to the atmosphere from anthropogenic sources worldwide. Environ Rev 9:269-298 (2001).
48 Shen $\mathrm{H}$ and Forssberg $\mathrm{E}$, An overview of recovery of metals from slags. Waste Manage 23:933-949 (2003).

49 Beyersmann D and Hartwig A, Carcinogenic metal compounds: recent insight into molecular and cellular mechanisms. Arch Toxicol 82:493-512 (2008).

50 Campos MGR, Bogdanov S, Almeida-Muradian LB, Szczesna T, Mancebo Y, Frigerio $C$ et al., Pollen composition and standardization of analytical methods. J Apic Res Bee World 47:154-161 (2008).

51 Zamberlin S, Antunac N, Havranek J and Samardžija D, Mineral elements in milk and dairy products. Mljekarstvo 62:111-125.

52 Belitz H-D, Grosch W and Schieberle P, Food Chemistry. Springer, Berlin, pp. 422-423 (2009) 